\title{
Susceptibility of provenances and families of Pinus maximinoi and Pinus tecunumanii to frost in South Africa
}

\author{
R. G. Mitchell ${ }^{1}$, M. J. Wingfield ${ }^{2}$, G. R. Hodge ${ }^{3}$, W. S. Dvorak ${ }^{3}$ and T. A. Coutinho ${ }^{2}$ \\ ${ }^{1}$ York Timbers, Tree Breeding Division, Sabie, South Africa. gmitchell@york.co.za \\ ${ }^{2}$ Department of Microbiology and Plant Pathology, Forestry and Agricultural Biotechnology \\ Institute (FABI), University of Pretoria, South Africa \\ ${ }^{3}$ Department of Forestry and Environmental Resources, North Carolina State University, USA
}

\begin{abstract}
The future of South Africa's most important pine species, Pinus patula, is threatened by the pitch canker fungus, Fusarium circinatum. Pinus maximinoi and P. tecunumanii represent two subtropical species that provide an alternative to planting $P$. patula on the warmer sites of South Africa. Extending the planting range of $P$. tecunumanii and $P$. maximinoi to include higher and colder altitude sites will reduce the area planted to $P$. patula and the risk of $F$. circinatum. During 2007 progeny trials of $P$. tecunumanii and $P$. maximino $i$ were planted on a sub-tropical and sub-temperate site. Shortly after the establishment of these trials, unusually cold weather conditions were experienced across South Africa $\left(-3^{\circ} \mathrm{C}\right.$ at the sub-temperate site) resulting in severe mortality. This provided the opportunity to assess the variation in survival as a measure of frost tolerance within these two species to determine whether it could be improved upon through selection. Results indicated that the variation in survival was under genetic control in $P$. tecunumanii $\left(\mathrm{h}_{(0,1)}^{2}=0.16, \mathrm{~h}_{\mathrm{L}}^{2}=0.27\right)$ and P. maximinoi $\left(\mathrm{h}_{(0,1)}^{2}=0.11, \mathrm{~h}_{\mathrm{L}}^{2}=0.23\right)$ at the subtemperate site. Correlations in provenance ranking for survival across sites were high for both species. Moderate correlations in family survival for $P$. tecunumanii $(\mathrm{r}=0.52)$ were found at the two sites. Improvements in cold tolerance can thus be made in both species extending their planting range to include greater areas planted to $P$. patula thereby limiting the risk of $F$. circinatum.
\end{abstract}


Keywords; Camcore, genetic diversity, frost susceptibility, South Africa, Pinus maximinoi, Pinus tecunumanii.

\section{Introduction}

There is considerable interest in commercializing alternative pine species not commonly planted in South Africa. This emerges from a desire to improve several weaker characteristics of currently deployed species, including the susceptibility of Pinus patula to the pitch canker fungus, Fusarium circinatum. Pinus tecunumanii and P. maximinoi are two alternative species that have shown good growth (Kietza 1988; Dvorak et al. 2000a, b; Gapare et al. 2001), wood properties (Malan 1994, 2006), and tolerance to F. circinatum (Hodge and Dvorak 2000, 2007; Mitchell et al. 2011). P. tecunumanii may be a particularly valuable species because it hybridises easily with South Africa's most important pine, P. patula, resulting in improved tolerance of the hybrid to F. circinatum (Roux et al. 2007).

Pinus tecunumanii and P. maximinoi are susceptible to frost that limits their planting to warmer sites. Populations of $P$. tecunumanii can be divided into those that occur below $1500 \mathrm{~m}$ altitude (low elevation subgroup) and those that occur above $1500 \mathrm{~m}$ (high elevation subgroup) in their natural origin in Central America and Mexico (Dvorak 1986; Dvorak et al. 2000a). High and low elevation subgroups of the species also are distinguishable genetically through molecular marker assessment (Dvorak et al. 2009). From a climatic standpoint, low elevation provenances are more tropical in nature and particularly sensitive to frost while high elevation provenances from southern Mexico and Guatemala can tolerate light frost (Dvorak et al. 2000a). Similarly, P. maximinoi grows best on tropical or sub-tropical sites free from frost (Dvorak et al. 2000b). Improving the frost tolerance of these two species would increase their planting range to include warm and sub-temperate sites currently planted to $P$. patula.

During 2007, progeny trials of $P$. tecunumanii and $P$. maximinoi were established just before a winter period. The survival of these trials was severely affected by a frost event resulting in their 
termination. In this study the survival data were examined and tolerance of these two species to frost was determined.

\section{Methods}

A group of 113 P. tecunumanii and 43 P. maximinoi trees (hereafter called "selections") were identified in $1^{\text {st }}$ generation provenance / progeny trials planted by Komatiland Forests. Selection criteria were provenance and family growth, and individual tree growth and form. The trials were then heavily thinned, effectively converting the progeny tests into seedling orchards. Seed was collected from the selections, and was sown at the Komatiland Forest's nursery near Sabie in September 2006. Sufficient seed was sown to plant two second-generation trials of each species on two separate predetermined sites (Spitskop and Wilgeboom). The Spitskop site could be described as sub-temperate while the Wilgeboom site is sub-tropical. The $1^{\text {st }}$ generation selections represented a number of the original provenances from different countries in Central America and southern Mexico (Table 1), which had been planted in blocks. The selections were, therefore, likely to have been pollinated by surrounding trees of the same provenance, but may also have been pollinated by trees further away and not necessarily of the same provenance. Seedlings were raised in 128 Unigro plastic molded trays with an individual cavity size of $60 \mathrm{cc}$. Well-composted pine bark was used as the growing medium and 2:3:2 (22) N:P:K granular fertilizer was applied as required.

The trials were planted in mid-March 2007 when seedlings were 6-months-old. At each site, one P. maximinoi and one P. tecunumanii trial was planted. Based on the availability of seedlings, the Wilgeboom trials were comprised of the full set of families whilst the Spitskop trials contained fewer families. In the case of both species, the families in the Spitskop trials were common in the Wilgeboom trials. In each case, the trial design was a randomized complete block with 6 replications and 6 tree family row plots. Each family, therefore, was represented by 36 trees in each trial. In all the trials Pinus elliottii and P. patula seedlings from a commercial seed orchard were used as controls. 
The trials were assessed for survival after 60 days and blanked to 100\% stocking. Approximately 5 days after the blanking operation, extremely cold conditions were experienced across the country. The nearest weather station was at Graskop, a town approximately halfway between the two sites, and of similar altitude $(1450 \mathrm{~m})$ and climate to the sub-temperate Spitskop site. Weather data for the month of May showed that temperatures dropped to below freezing ( 0 to $3^{\circ} \mathrm{C}$ ) for four consecutive days, and below $5^{\circ} \mathrm{C}$ for 9 consecutive days, between $21-29 / 05 / 07$ at Graskop (Fig. 1). Soon after the frost event (75 days from the original planting), the trials were reassessed for survival. Severe mortality was recorded at the sub-temperate Spitskop site while less damage was recorded at the sub-tropical Wilgeboom site.

\section{Statistical analyses}

The statistical package SAS version 9.1.3 (SAS Institute 2004) was used to analyse the data in which case individual tree observations, recorded as dead (0) or alive (1), were used as the unit of analysis. Several analyses of variance were conducted using SAS Proc GLM on each of the four individual tests (P. tecunumanii and P. maximinoi on the Spitskop and Wilgeboom sites). In all analyses, the binomial survival data was used as the units of observation.

Although inter-mating among trees from different provenances would have occurred in the thinned $1^{\text {st }}$ generation progeny tests, the original provenance of a family could very likely have an impact on frost tolerance of the second-generation families. To investigate this, an analysis of variance was done to compare the control species, P. patula and P. elliottii, to the country and provenance of origin for P. tecunumanii and P. maximinoi. The linear model contained rep and country treated as fixed effects, and provenance, family(provenance), and rep*family(provenance) treated as random effects. SAS Proc GLM was used to conduct the analysis of variance, and least squares means (LS means) were calculated along with the pvalues testing for statistically significant difference for each pair of means. A second GLM analysis was done using only the species data sets on each test site (that is, removing the control species), in order to test for differences among provenance and family (provenance). As above, in this model, rep was treated as fixed effects, while provenance, family(provenance), and rep*family(provenance) were treated as random effects, and LS means calculated as described 
above. A Pearson correlation was calculated between provenance and family means on the two sites for each species separately

To examine the potential to breed for frost tolerance in the two species, genetic parameters for the populations were calculated with SAS Proc MIXED, using a linear model with rep treated as a fixed effect, and family and rep*family were treated as random effects. As the families were represented by open-pollinated seed collected in seedling seed orchards, converted from progeny tests, a coefficient of 3 provides a better estimate of additive genetic variance (Dieters et al. 1995). Heritability was calculated on the observed (binomial) scale, as $h_{(0,1)}^{2}=3 \sigma_{\mathrm{f}}^{2} /\left(\sigma_{\mathrm{f}}^{2}+\sigma_{\text {plot }}^{2}\right.$

$+\sigma_{\text {error }}^{2}$ where $\sigma_{\mathrm{f}}^{2}=$ estimated family variance, $\sigma_{\text {plot }}^{2}=$ estimated rep*family(provenance) variance, and $\sigma_{\text {error }}^{2}=$ estimated residual variance. The heritability estimate on the binomial scale was then converted to an estimate on the underlying liability scale $\left(\mathrm{h}_{\mathrm{L}}^{2}\right)$ following the methodology of Chambers et al. (1996). Standard errors of the heritability were estimated using the approximation formula (Dickerson 1962), with the standard error of the family variance estimate calculated from the ASYCOV option in Proc MIXED.

\section{Results}

Due to the more extreme temperatures, fewer plants survived at Spitskop than at Wilgeboom. The mean survival for $P$. tecunumanii (LE) was $27 \%$ and $46 \%$ for $P$. tecunumanii (HE) at Spitskop compared to $85.1 \%$ and $93.6 \%$, respectively, at the Wilgeboom site. In the $P$. tecunumanii trial at Spitskop, P. patula survived better (83\%) than P. elliottii (69\%) compared to $100 \%$ survival for both species at the Wilgeboom site. The survival of $P$. maximinoi at the Spitskop site was $19 \%$ compared to $87 \%$ at Wilgeboom. In the $P$. maximinoi trials $P$. patula survival (89\%) was poorer than P. elliottii (97\%) at Spitskop and similar to P. elliottii at Wilgeboom (97\% vs. 94\%).

In the $P$. tecunumanii trials, the means of the HE families, which originated from southern Mexico and Guatemala, were significantly better than the mean of the LE families from Honduras at both sites (Table 3). The single high elevation variety of $P$. tecunumanii 
representing Honduras (Las Trancas) was significantly poorer than the mean of the high elevation families from Guatemala and Mexico at the Spitskop site. In the P. maximinoi trials, families that originated from Honduras ranked better than those from Mexico that ranked better than those from Guatemala at both sites (Table 3). However, there were no significant differences between the means for each country at either site.

An analysis of provenance differences, which were represented by at least 2 families at a single site, indicated that the $P$. tecunumanii high elevation provenances (San Lorenso, Chempil, Montebello and San Jerónimo) survived significantly better than the $P$. tecunumanii low elevation provenances (San Esteban, San Francisco, Jocon and Villa Santa) at both the Spitskop and Wilgeboom sites (Table 4). Within the P. tecunumanii high elevation subgroup, the San Lorenso and Montebello provenances survived significantly better than the San José and Las Trancas provenances planted at the Spitskop site and the San José and Jitotal provenances at the Wilgeboom site (Table 4). Within the low elevation subgroup, the Villa Santa provenance survived significantly more poorly than the other LE provenances at the Spitskop site (Table 4). When comparing the ranking of provenances represented by at least 2 families at each site, there was a high correlation between the survival means on the two sites (Table 4).

There was no significant difference for all provenances of $P$. maximinoi at either site (Table 4), despite the fact that the LS means for survival ranged from $13.3 \%$ to $27.8 \%$ at Spitskop, and from $83.8 \%$ to $93.5 \%$ at Wilgeboom. Despite there being no significant differences between $P$. maximinoi provenances at either site, there was a high correlation between the survival means on the two sites (Table 4).

There was large family variation in survival at the Spitskop site for P. tecunumanii of both the low (3-61\%) and high (11-78\%) elevation subgroups. At the Spitskop site, a number of high elevation families showed little frost tolerance and some low elevation families showed frost tolerance similar to the mean of the high elevation variety (Fig. 2). The range of family survival in P. maximinoi at the Spitskop site was smaller, with the most tolerant family measuring 38\% survival (Fig. 3). There was little variation at the Wilgeboom site for both species and it is likely that only the most susceptible families showed some mortality. Narrow-sense heritability 
estimates for the trials at Spitskop were good for P. tecunumanii $\left(\mathrm{h}^{2}{ }_{(0,1)}=0.16, \mathrm{~h}_{\mathrm{L}}^{2}=0.27\right)$ and weaker for P. maximinoi $\left(\mathrm{h}_{(0,1)}^{2}=0.11, \mathrm{~h}_{\mathrm{L}}^{2}=0.23\right)$ (Table 5). Narrow-sense heritability at the Wilgeboom site was poor for P. tecunumanii $\left(\mathrm{h}_{(0,1)}^{2}=0.05, \mathrm{~h}_{\mathrm{L}}^{2}=0.12\right)$ and was nil for $P$. maximinoi (Table 5). The correlation between $P$. tecunumanii families was stronger $(\mathrm{r}=0.52)$ than P. maximinoi (r=0.37) (Figs. 4-5).

\section{Discussion}

This study provides quantitative evidence that frost tolerance is under genetic control in $P$. tecunumanii and P. maximinoi, which is similar to that observed in other pine species (Rehfeldt 1989; Duncan et al. 1996; Howe 2006). A substantial amount of the observed family variance in the selected population for $P$. tecunumanii appears related to the original country and provenance origin. These provenance effects were consistent across two distinct environments that were widely different in their frost survival means.

In this study, frost tolerance was measured using a binomial trait. Survival for both species on both sites was near the low or high end of the scale (19\% for $P$. maximinoi and $33 \%$ for $P$. tecunumanii at Spitskop, and $86 \%$ for both species at Wilgeboom). Despite there being no significant differences between P. maximinoi provenances (Table 4), the ranking in survival on the two sites were very similar. Heritability estimates on the binomial scale were rather low, but on the underlying liability scale, $\mathrm{h}_{\mathrm{L}}^{2}$ estimates of 0.23 to 0.27 for the two species at the Spitskop site indicates that frost tolerance in both species could be improved through breeding and selection. Pinus maximinoi appeared to be more susceptible to cold damage than P. tecunumanii. Since breeding would begin with a lower mean tolerance in the population, it may require multiple generations to make any significant improvement in the frost tolerance of this species. Compared to $P$. maximinoi, the broader range of family tolerance in $P$. tecunumanii (particularly of the high-elevation subgroup) and slightly higher heritability suggests that advances in breeding for frost tolerance in P. tecunumanii would be more easily achieved.

The P. tecunumanii high elevation provenances, Montebello, San Jerónimo and Chempil, which ranked as some of the more frost tolerant provenances in this study, have been found to be 
significantly more susceptible to $F$. circinatum than the high elevation provenances of Jitotol and Las Trancas (Mitchell et al. 2011), which were less tolerant of frost. Similarly, Villa Santa, which was significantly more frost susceptible compared to other low elevation provenances in this study, ranked as the most tolerant provenance to F. circinatum (Mitchell et al. 2011). This suggests that there is an inverse relationship between frost tolerance and tolerance to $F$. circinatum within $P$. tecunumanii. This means that selecting and breeding for frost tolerance in $P$. tecunumanii, and increasing the distribution of more frost tolerant selections to cool sites as a replacement for $P$. patula, may be limited by a decline in tolerance to F. circinatum.

Subsequent to the frost event in 2007, both species were replanted in February 2008 at the Wilgeboom site and P. tecunumanii was replanted at the Spitskop site in the same month. The survival was excellent at both sites. This illustrates that planting these species in a warmer month, followed by a normal winter period, can be successful. However, from our experience planting these species on sites, where frequent frost events are a normal occurrence and later than February in South Africa, should be avoided until their frost tolerance can be improved.

It is known that hybridizing frost-susceptible with tolerant species can provide an effective means to improve frost tolerance (Duncan et al. 1996). Therefore, to compliment breeding for frost tolerance, $P$. tecunumanii and $P$. maximinoi could be hybridized with tolerant species (such as P. patula). In such cases, whilst an improvement in frost tolerance can be seen, the frost tolerance of the hybrid may more closely resemble the susceptible parent (Duncan et al. 1996). This may be the experience in South Africa, where the P. patula $x$ P. tecunumanii hybrid has become very popular due to its improved tolerance to F. circinatum (Roux et al. 2007), it remains susceptible to frost especially when the low elevation subgroup is used as the pollen parent. It is likely, however, that the susceptibility of $P$. patula $x P$. tecunumanii to frost can be improved upon by backcrossing it with P. patula as reported for other species (Lopez-Upton et al. 1999). Importantly, the tolerance of hybrid families to frost seems more reliant on the specific combining ability of the parents and not necessarily the tolerance of the parents themselves (Duncan et al. 1996). Therefore, it seems likely that families of P. patula $\times$ P. tecunumanii, and not only the parents, would need to be tested for frost tolerance as well as for tolerance to $F$. 
circinatum in the future. This would also be the case where $P$. maximinoi is hybridized with other frost tolerant species.

As seen in this study, and elsewhere (Lopez-Upton et al. 1999, Howe 2006, Dong et al. 2009), exposing young trees to cold temperatures in field trials may be an effective method to identify frost tolerant individuals. Based on our experience, temperatures slightly below freezing, for several hours per day for several days in the field should be sufficient to screen families for tolerance in P. tecunumanii and P. maximinoi in the field. However, a number of artificial screening methods have also been described (Rehfeldt 1989; South et al. 1993; Tinus et al. 2002; Mahalovich et al. 2006; Aldrete et al. 2008). Artificial tests using either seedlings/cuttings or needles, can be subjected to freezing temperatures in a controlled environment. After thawing, needles can simply be assessed for discoloration and bending ability and then the amount of damage scored (Rehfeldt 1989; South et al. 1993). Alternatively the amount of electrolyte leakage from the damaged tissue can be scored (South et al. 1993; Tinus et al. 2002; Mahalovich et al. 2006; Aldrete et al. 2008). The results of these artificial tests often compare well with observations in the field (Howe 2006; Dvorak pers. comm. 2010). Whichever method is chosen to identify tolerant provenances and individuals, it will become increasingly important to improve the tolerance of subtropical species, such as $P$. tecunumanii and $P$. maximinoi to cold temperatures in South Africa.

\section{Conclusions and Outlook}

There was good evidence from this study that the frost susceptibility of $P$. tecunumanii and $P$. maximino $i$ is under genetic control, and can be improved by selecting provenances and families that are more tolerant to frost. Our hope is that through selection, we can eventually build up a sizeable population of individual trees with good frost tolerance and good growth. In order to maximize the potential that $P$. tecunumanii and $P$. maximinoi offer, particularly to reduce the risk posed by $F$. circinatum, frost tolerance will have to be included as a future selection criterion. Results of this study show that his can be achieved by planting provenances and families in cold climates and then recording mortality. Alternatively, various laboratory techniques should be 
explored to rapidly screen provenance and families that are most cold hardy. These can then be more thoroughly tested in the field under natural climatic conditions.

\section{Acknowledgements}

We thank Komatiland Forests for making available the data from these trials for publication.

\section{References}

Aldrete A, Mexal JG, Burr KE (2008) Seedling cold hardiness, bud set, and bud break in nine provenances of Pinus greggii Englm. Forest Ecology and Management 255: 3672-3676

Dickerson GE (1969) Techniques for research in quantitative animal genetics. In: Techniques and procedures in animal science research. Am Soc Anim Sci, Albany, N.Y., pp 36-79.

Dieters MJ, White TL, Hodge GR (1995) Genetic parameter estimates for volume from full-sib tests of slash pine (Pinus elliottii). Canadian Journal of Forest Research 25: 1397-1408.

Dong J, LinY, Yu S, Wang Q, Lu A, Feng J, Liu Y, Man S, Qu Y (2009) Selection of superior provenance of eastern white pine by cold resistance. Journal of Northeast Forestry University 37: 4-6.

Duncan PD, White TL, Hodge GR (1996) First-year freeze hardiness of pure species and hybrid taxa of Pinus elliottii (Engelman) and Pinus caribaea (Morelet). New Forests 212: 223241.

Dvorak WS (1986) Provenance/progeny testing of Pinus tecunumanii. In: Proc IUFRO Breeding theory, progeny testing and seed orchard management. Williamsburg, VA. October 1217. pp: 299-309.

Dvorak WS, Gutiérrez EA, Galpare WJ, Hodge GR, Ororio LF, Bester C, Kikuti P (2000b) Pinus maximinoi. In: Conservation \& Testing of Tropical \& Subtropical Forest Tree Species by the CAMCORE Cooperative, College of Natural Resources, NCSU, Raleigh, NC, USA. pp $107-127$.

Dvorak WS, Hodge GR, Gutiérrez EA, Osorio LF, Malan FS, Stanger TK (2000a) Pinus tecunumanii. In: Conservation \& Testing of Tropical \& Subtropical Forest Tree Species 
by the CAMCORE Cooperative. College of Natural Resources, North Carolina State University. 188-209.

Dvorak WS, Potter KM, Hipkins VD, Hodge GR (2009) Genetic diversity and gene exchange in Pinus oocarpa, a Mesoamerican pine with resistance to the pitch canker fungus (Fusarium circinatum). International Journal of Plant Sciences 170:609-626.

Gapare W, Hodge GR, Dvorak WS (2001) Genetic parameters and provenance variation of Pinus maximinoi in Brazil, Colombia, and South Africa. Forest Genetics 8: 159-170

Hodge GR, Dvorak WS (2000) Differential responses of Central American and Mexican pine species and Pinus radiata to infection by the pitch canker fungus. New Forests 19: 241258.

Hodge GR, Dvorak WS (2007) Variation in pitch canker resistance among provenances of Pinus patula and Pinus tecunumanii from Mexico and Central America. New Forests 33:193 206.

Howe K (2006) Identifying candidate genes associated with cold adaptation in Douglas-fir using DNA microarrays. Oregon State University in partial fulfillment of Master of Science.

Kietza JE (1988) Pinus maximinoi: A promising species in South Africa. Southern African Forestry Journal 145: 33 - 38.

López-Upton J, White TL, Huber DA (1999) Taxon and family differences in survival, cold hardiness, early growth, and rust incidence of Loblolly pine, Slash pine and some Pine hybrids. Silvae Genetica 48:303-313.

Mahalovich MF, Burr KE, Foushee DL (2006) Whitebark pine germination, rust resistance and cold hardiness among seed sources in the inland northwest: planting strategies for restoration. USDA Forest Service Proceedings RMRS-P-43; 91-101.

Malan FS (1994) The quality and wood properties of 4 provenances of South-African-grown Pinus tecunumanii. Ann Sci For. 51: 203-212.

Malan FS (2006) The wood properties and sawn-board quality of South African-grown Pinus maximinoi (HE Moore). Southern African Forestry Journal 208: 39 - 48.

Mitchell RG, Wingfield MJ, Hodge GR, Steenkamp ET, Coutinho TA (2011) Selection of Pinus spp. in South African for tolerance to infection by the pitch canker fungus. New Forests (in print http://www.springerlink.com/content/j02181n158286311). 
Rehfeldt GE (1989) Genetic variances and covariances in freezing tolerance of lodgepole pine during early winter acclimation. Silvae Genetica 38: 133-137

Roux J, Elsenberg B, Kanzler A, Nel A, Coetzee V, Kietzka E, Wingfield MJ (2007) Testing of selected South African Pinus hybrids and families for tolerance to the pitch canker pathogen, Fusarium circinatum. New Forests 33: 109 - 123.

SAS Institute (2004) SAS® 9.1.3 ETL Studio: User's Guide. Cary, NC, USA.

South D, Donald DGM, Rakestraw JL (1993) Effect of nursery culture and bud status on freeze injury to Pinus taeda and P. elliottii seedlings. South African Forestry Journal 166:3746.

Tinus RW, Sword M, Barnett JP (2002) Prevention of cold damage to container-grown longleaf pine roots. General Technical Report SRS-56, Ashville, NC, USDA Forest Service, Southern Research station, p 55-57. 
Table 1: Number of families representing provenances

\begin{tabular}{|c|c|c|c|c|c|c|}
\hline Species & Ecotype & Provenance & State & Country & Wilgeboom & Spitskop \\
\hline Pinus & NA & Coban & Alta Verapaz & Guatemala & 6 & 5 \\
\hline \multirow[t]{11}{*}{ maximino $i$} & & San Jeronimo & Baja Verapaz & Guatemala & 10 & 9 \\
\hline & & San Juan Sacatep. & Guatemala & Guatemala & 6 & 5 \\
\hline & & San Lorenzo & Zacapa & Guatemala & 1 & 1 \\
\hline & & Copan & Copan & Honduras & 3 & 2 \\
\hline & & Tatumbla & Fco. Morazán & Honduras & 3 & 3 \\
\hline & & Marcala & $\mathrm{La} \mathrm{Paz}$ & Honduras & 3 & 2 \\
\hline & & El Portillo & Ocotepeque & Honduras & 3 & 3 \\
\hline & & Altamirano & Chiapas & Mexico & 1 & 1 \\
\hline & & La Canada & Chiapas & Mexico & 2 & 2 \\
\hline & & Monte Cristo & Chiapas & Mexico & 1 & 1 \\
\hline & & San Jerónimo & Chiapas & Mexico & 4 & 4 \\
\hline Total & & & & & 43 & 38 \\
\hline Pinus & High & San Jerónimo & Baja Verapaz & Guatemala & 7 & 4 \\
\hline \multirow[t]{14}{*}{ tecunumanii } & High & KM 47 & Guatemala & Guatemala & 1 & 1 \\
\hline & High & La Soledad & Jalapa & Guatemala & 1 & 1 \\
\hline & High & San Lorenzo & Zacapa & Guatemala & 3 & 2 \\
\hline & High & Las Trancas & $\mathrm{LaPaz}$ & Honduras & 3 & 2 \\
\hline & High & Chempil & Chiapas & Mexico & 13 & 9 \\
\hline & High & Jitotol & Chiapas & Mexico & 3 & 3 \\
\hline & High & Las Piedrecitas & Chiapas & Mexico & 2 & 1 \\
\hline & High & Montebello & Chiapas & Mexico & 8 & 6 \\
\hline & High & Napite & Chiapas & Mexico & 2 & 1 \\
\hline & High & San José & Chiapas & Mexico & 2 & 2 \\
\hline & Low & Jocon & Yoro & Honduras & 4 & 2 \\
\hline & Low & San Esteban & Olancho & Honduras & 13 & 9 \\
\hline & Low & San Francisco & Olancho & Honduras & 18 & 15 \\
\hline & Low & Villa Santa & El Paraiso & Honduras & 33 & 26 \\
\hline $\begin{array}{l}\text { Total } P \text {. } \\
\text { tecunumanii }\end{array}$ & & & & & 113 & 84 \\
\hline
\end{tabular}

$\mathrm{NA}=$ Not applicable 
Table 2: Site details where the Pinus maximinoi and Pinus tecunumanii trials were planted in South Africa

\begin{tabular}{l|ll}
\hline Trial site & Wilgeboom & Spitskop \\
\hline Location & $30^{\circ} 56^{\prime} 19^{\prime \prime} \mathrm{E} ; 245^{\prime} 5^{\prime \prime} \mathrm{S}$ & $30^{\circ} 50^{\prime} 23^{\prime \prime} \mathrm{E} ; 259^{\prime} 37^{\prime} \mathrm{S}$ \\
Description & Sub-tropical & Sub-temperate \\
Altitude & $983 \mathrm{~m}$ & $1480 \mathrm{~m}$ \\
Mean min temperature in coldest month & $5^{\circ} \mathrm{C}$ & $4^{\circ} \mathrm{C}$ \\
Mean annual temperature & $18.5^{\circ} \mathrm{C}$ & $15^{\circ} \mathrm{C}$ \\
Mean max temperature in warmest month & $27^{\circ} \mathrm{C}$ & $24^{\circ} \mathrm{C}$ \\
Mean annual precipitation & $1100 \mathrm{~mm}$ & $1266 \mathrm{~mm}$ \\
Plant date (day 0) & $4-15 / 03 / 2007$ & $12-13 / 03 / 2007$ \\
Blank date (day 60) & $14 / 05 / 2007$ & $15 / 05 / 2007$ \\
Assessment date (day 75) & $30 / 05 / 2007$ & $31 / 05 / 2007$ \\
\hline
\end{tabular}

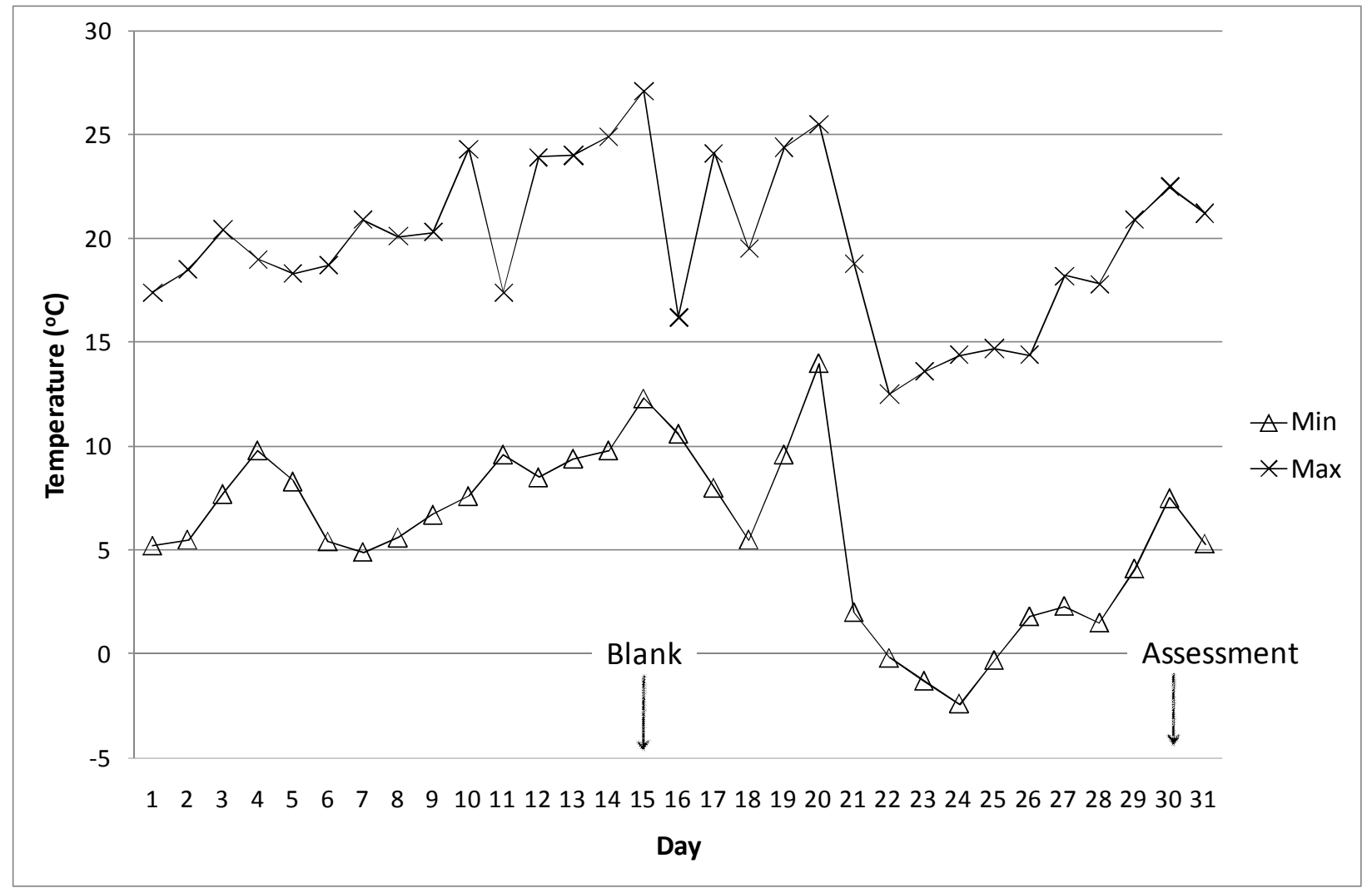

Figure 1. Minimum and maximum temperatures recorded, at a nearby weather station representative of the cool-temperate Spitskop site, for the month of May 2007. 
Table 3. The least square mean survival by country ranked from best to worst for $P$. tecunumanii and P. maximinoi.

\begin{tabular}{l|lll}
\hline Species & Country & Spitskop (\%) & Wilgeboom (\%) \\
\hline Pinus tecunumanii & P. patula & $83.3^{\mathrm{A}}$ & $100^{\mathrm{A}}$ \\
& P. elliottii & $69.4^{\mathrm{A}}$ & $100^{\mathrm{A}}$ \\
& Mexico (HE) & $52.2^{\mathrm{B}}$ & $92.0^{\mathrm{A}}$ \\
& Guatemala (HE) & $48.3^{\mathrm{B}}$ & $95.4^{\mathrm{A}}$ \\
& Honduras (HE) & $34.7^{\mathrm{C}}$ & $88.9^{\mathrm{AB}}$ \\
& Honduras (LE) & $26.6^{\mathrm{C}}$ & $85.3^{\mathrm{B}}$ \\
\hline Pinus maximinoi & P. elliottii & $97.2^{\mathrm{B}}$ & $94.4^{\mathrm{A}}$ \\
& P. patula & $88.9^{\mathrm{B}}$ & $97.2^{\mathrm{A}}$ \\
& Honduras & $21.4^{\mathrm{A}}$ & $89.8^{\mathrm{A}}$ \\
& Mexico & $18.8^{\mathrm{A}}$ & $86.1^{\mathrm{A}}$ \\
& Guatemala & $16.3^{\mathrm{A}}$ & $85.5^{\mathrm{A}}$ \\
\hline
\end{tabular}

Treatments with different letters, for each species separately, are significantly different $(\mathbf{p}<\mathbf{0 . 0 5})$. 
Table 4. The least square mean survival by provenance (represented by at least 2 families) of $P$. tecunumanii and $P$. maximinoi ranked from best to worst at the Spitskop site.

\begin{tabular}{l|lllll}
\hline Species & Provenance & State & Country & Spitskop (\%) & Wilgeboom (\%) \\
\hline P. tecunumanii & P. elliottii control & Local source & South Africa & $83.3^{\mathrm{A}}$ & $100^{\mathrm{A}}$ \\
& P. patula control & Local source & South Africa & $69.4^{\mathrm{AB}}$ & $100^{\mathrm{A}}$ \\
& San Lorenso (HE) & Zacapa & Guatemala & $52.8(2)^{\mathrm{BCD}}$ & $98.1(3)^{\mathrm{AB}}$ \\
& Montebello (HE) & Chiapas & Mexico & $52.4(6)^{\mathrm{CD}}$ & $96.5(8)^{\mathrm{AB}}$ \\
& San Jerónimo (HE) & Baja Verapaz & Guatemala & $45.0(4)^{\mathrm{CDE}}$ & $93.7(7)^{\mathrm{ABC}}$ \\
& Chempil (HE) & Chiapas & Mexico & $44.0(9)^{\mathrm{CE}}$ & $94.0(13)^{\mathrm{ABC}}$ \\
& Jitotol (HE) & Chiapas & Mexico & $41.7(3)^{\mathrm{CEF}}$ & $88.0(3)^{\mathrm{CD}}$ \\
& San José (HE) & Chiapas & Mexico & $36.1(2)^{\mathrm{EFG}}$ & $87.5(2)^{\mathrm{CD}}$ \\
& Las Trancas (HE) & La Paz & Honduras & $34.7(2)^{\mathrm{EFG}}$ & $88.9(3)^{\mathrm{AC}}$ \\
& Jocon (LE) & Yoro & Honduras & $30.6(2)^{\mathrm{FGH}}$ & $86.8(4)^{\mathrm{D}}$ \\
& San Esteban (LE) & Olancho & Honduras & $26.7(9)^{\mathrm{GH}}$ & $85.3(13)^{\mathrm{D}}$ \\
& San Francisco (LE) & Olancho & Honduras & $26.1(15)^{\mathrm{GH}}$ & $83.6(18)^{\mathrm{D}}$ \\
& Villa Santa (LE) & El Paraiso & Honduras & $22.9(26)^{\mathrm{D}}$ & $85.7(33)^{\mathrm{D}}$ \\
\hline Pinus maximinoi & P. elliottii control & Local source & South Africa & $97.2^{\mathrm{B}}$ & $94.4^{\mathrm{A}}$ \\
& P. patula control & Local source & South Africa & $88.99^{\mathrm{B}}$ & $97.2^{\mathrm{A}}$ \\
& Marcala & La Paz & Honduras & $27.8(2)^{\mathrm{A}}$ & $93.5(3)^{\mathrm{A}}$ \\
& La Canada & Chiapas & Mexico & $23.6(2)^{\mathrm{A}}$ & $86.1(2)^{\mathrm{A}}$ \\
& Tatumbla & Fco. Morazán & Honduras & $21.3(3)^{\mathrm{A}}$ & $88.9(3)^{\mathrm{A}}$ \\
& San Juan Sacatepéquez & Guatemala & Guatemala & $19.4(5)^{\mathrm{A}}$ & $86.1(6){ }^{\mathrm{A}}$ \\
& San Jerónimo & Chiapas & Mexico & $17.9(4)^{\mathrm{A}}$ & $85.3(4)^{\mathrm{A}}$ \\
& San Jerónimo & Baja Verapaz & Guatemala & $17.4(9)^{\mathrm{A}}$ & $86.8(10)^{\mathrm{A}}$ \\
& El Portillo & Ocotepeque & Honduras & $16.7(3)^{\mathrm{A}}$ & $87.0(3)^{\mathrm{A}}$ \\
& Coban & Alta Verapaz & Guatemala & $13.3(5)^{\mathrm{A}}$ & $83.8(6)^{\mathrm{A}}$ \\
\hline
\end{tabular}

Figures in brackets are the number of families representing each provenance.

Treatments with different letters, for each species separately, are significantly different $(\mathbf{p}<\mathbf{0 . 0 5})$.

Table 5. Heritability estimates for Pinus maximinoi and $P$. tecunumanii at the two sites

\begin{tabular}{l|llllll}
\hline Model & Site & Species & h2(0,1) & se & h2(L) & se \\
\hline family & Spitskop & P. maximinoi & 0.11 & 0.04 & 0.23 & 0.09 \\
family & Spitskop & P. tecunumanii & 0.16 & 0.06 & 0.27 & 0.10 \\
family & Wilgeboom & P. maximinoi & 0.00 & 0.00 & 0.00 & 0.00 \\
family & Wilgeboom & P. tecunumanii & 0.05 & 0.03 & 0.12 & 0.07 \\
\hline
\end{tabular}



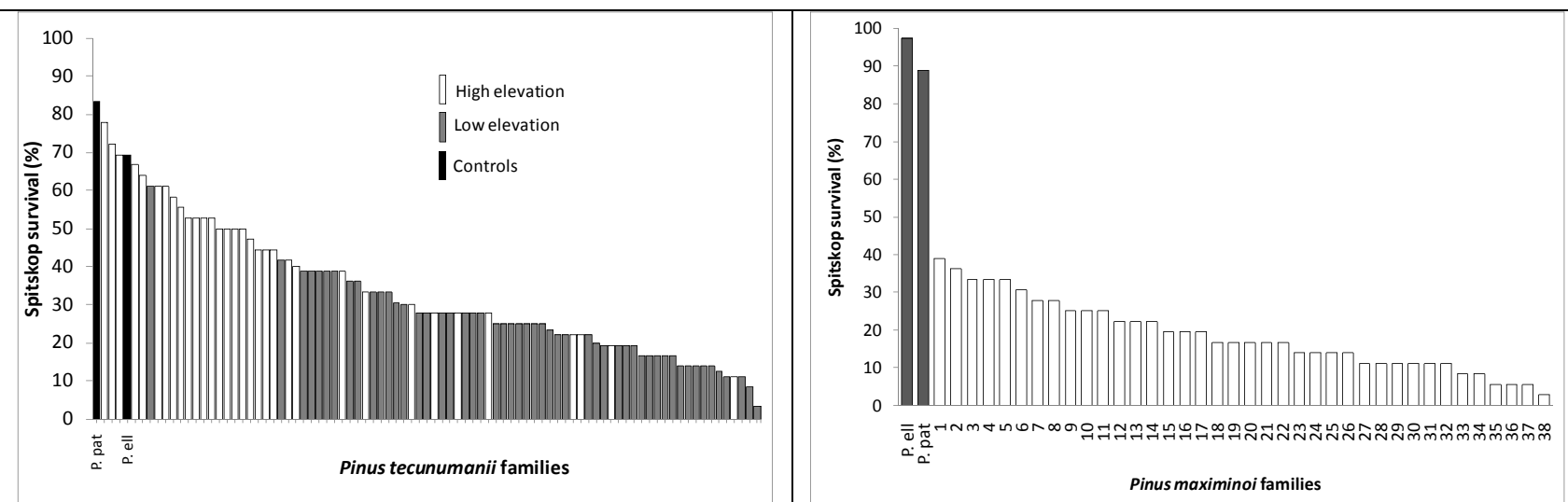

Figure 2. P. tecunumanii family survival on the cool-temperate site (Spitskop) $\left(\mathrm{h}^{2}{ }_{(0,1)}=0.16, \mathrm{~h}_{\mathrm{L}}^{2}\right.$ $=0.27)$.

Figure 3. P. maximinoi family survival on the cool-temperate site (Spitskop) $\left(\mathrm{h}^{2}{ }_{(0,1)}=0.11, \mathrm{~h}_{\mathrm{L}}^{2}\right.$ $=0.23$ ).
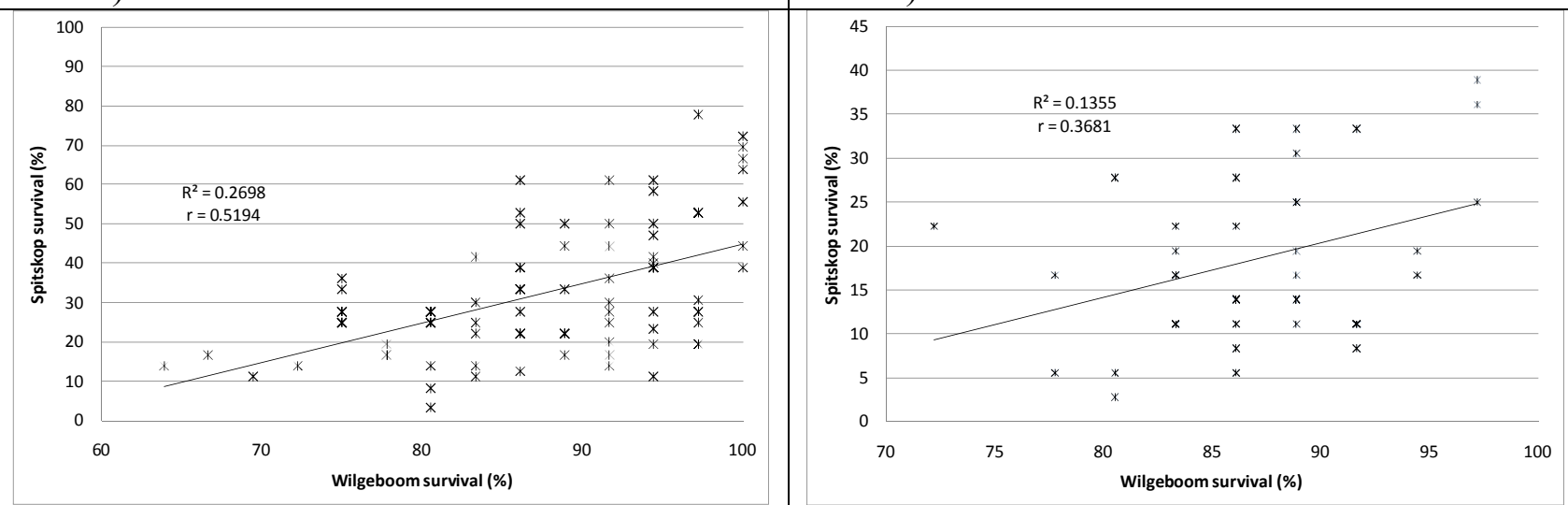

Figure 4. The correlation between all $P$. tecunumanii families at the two sites.

Figure 5. The correlation between all $P$. maximinoi families at the two sites. 